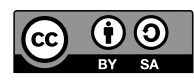

DOI: $10.4312 / \mathrm{mz} .56 .2 .35-50$

UDK 781:001.891(497.4)"20"

\title{
Contemporary Musicology and the Study of Musical Practices in Slovenia
}

\author{
Matjaž Barbo
}

University of Ljubljana

\begin{abstract}
Musicology in Slovenia is gradually evolving from a historiographical discipline into a system of intersecting research in the fields of reception history, institutional history, structural and genre analysis, acoustics, critical reflection, semiological analysis, hermeneutical reflection and epistemology. The discontinuities and inhomogeneities we perceive today can even be understood as one of the modes of contemporary musicology.
\end{abstract}

Keywords: musicology, contemporary musicology, Slovenian musicology

\section{IZVLEČEK}

Muzikologija na Slovenskem se iz zgodovinopisne discipline postopoma razvija v sistem navzkrižnih raziskav s področja recepcijske zgodovine, zgodovine institucij, strukturne in zvrstne analize, akustike, kritiške refleksije, semiološke analize, hermenevtske refleksije in epistemologije. Diskontinuiteto in nehomogenosti, ki jih zaznamo danes, lahko razumemo celo kot enega od modusov sodobne muzikologije.

Ključne besede: muzikologija, sodobna muzikologija, slovenska muzikologija 
On the occasion of the $200^{\text {th }}$ anniversary of the Academia philharmonicorum in 1902, Viktor Steska published a commemorative article in the journal Dom in svet (Home and World). ${ }^{1} \mathrm{He}$ concluded with the comment that the Philharmonic Society would shortly publish a historical overview of its "many years of activity", which he announces with a genial designation:

\section{This year, the 'Acad. Philoharm.' celebrates its bicentenary and gains the honour of being the oldest music society in the Austrian lands. It will shortly publish an interesting report on its many years of operation. I say 'interesting report' because it should arouse many memories, happy and sad, from bygone years, and fill our imaginations with an inexpressible charm. ${ }^{2}$}

Steska thus indicated the meaning and importance of musical historiography as he understood it himself: to arouse memories and fill the imagination with an inexpressible charm. With this, he largely indirectly also defined the primary importance of musicological work.

The "interesting report" of the Philharmonic Society to which Steska refers is, of course, most likely a chronicle based on Keesbacher's legacy that was edited and published by Emil Bock in the same year (1902). ${ }^{3}$

In the introduction, Bock modestly apologises for the fact that, in his opinion, the publication is not a genuine "history", but rather a commemorative anthology that is intended to speak of the most important events in the operation of the society:

Instead of the 'History', the management is now submitting this Festschrift to the honoured members of the Philharmonic Society and their friends with a concise overview of the most important events in our Society from its beginnings to the end of $1901 .{ }^{4}$

According to Bock, his record lacks the abundant research work that would be required in order for it to become a "complete, gapless history". However, his predecessors had not realised this ideal, either. Keesbacher, too, was severe and critical towards his own work. In the title of his first publication - a chronicle of the first decades of operation of the Philharmonic Society, which is today a priceless document for the contemporary Slovenian music historian - he gives the work the similarly modest label "historical sketch" (eine geschichtliche Skizze). ${ }^{5}$

1 Viktor Steska, "Academia Philo-Harmonicorum v Ljubljani: Ob dvestoletnici (1702-1902)," Dom in svet 15, no. 4 (1902): 234-237, http://www.dlib.si/?URN=URN:NBN:SI:DOC-21X3C5PZ.

2 Steska, "Accademia Philo-Harmonicorum," 237.

3 Emil Bock, Die Philharmonische Gesellschaft in Laibach: 1702-1902 (Ljubljana: Direktion der Philharmonischen Gesellschaft, 1902).

4 "An Stelle der 'Geschichte' unterbreitet nun die Direktion den geehrten Mitgliedern der philharmonischen Gesellschaft und deren Freunden vorliegende Festschrift mit einem gedrängten Überblicke über die wichtigsten Ereignisse unserer Gesellschaft von deren Anfange bis zum Ende des Jahres 1901.” Bock, Die Philharmonische Gesellschaft, 4.

5 Friedrich Keesbacher, Die Philharmonische Gesellschaft in Laibach seit dem Jahre ibrer Gründung 1702 bis zu ibrer letzten Umgestaltung 1862: Eine geschichtliche Skizze (Ljubljana, 1862). 
It is not without hesitation that I am handing this work over to the friends of the Philharmonic Society. On the one hand this work is quite alien to my previous literary activity, on the other hand the interest in it can only be a very limited one, like the framework within which the history of a musical society can of course only move. [...] What can most excuse the incompleteness of the little work is the difficulty in finding the necessary sources and evidence. ${ }^{6}$

It is as if Keesbacher were speaking about the current situation, as within Slovenian music historiography we can still conclude that our primary task is largely to seek out, identify and systematise primary sources. It is true that we also look for ways to interpret these sources, not least through meta interpretation in terms of the critical postmodern scepticism towards big stories or, as the present article is intended, by seeking traces of the development of Slovenian musicology and its true place within the contemporary humanities.

Keesbacher's observation that the number of readers interested in musicological writing is (increasingly) limited has not lost its relevance, either. By way of illustration, we can observe the decline in the borrowing of works by selected musicologists in recent years, as indicated in the figure below. ${ }^{7}$

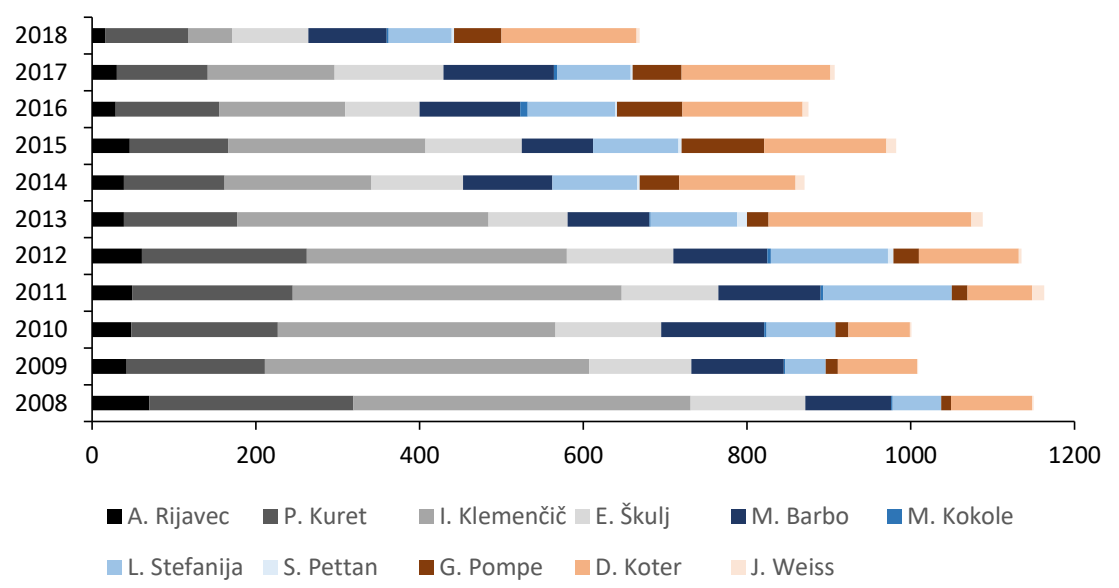

Figure 1: The decline in the borrowing of monographs by musicology authors in Slovenian libraries over the last ten years.

6 "Nicht Ohne Zagen übergebe ich diese Schrift den Freunden der philharmonischen Gesellschaft. Einestheils ist diese Arbeit meiner bisherigen literarischen Thätigkeit ganz fremdartig, anderntheils kann das Interesse für dieselbe nur ein sehr beschränktes sein, wie der Rahmen, innerhalb dessen sich die Geschichte einer Musikgesellschaft selbstverständlich nur bewegen kann. [...] Was die Unvollständigkeit des Werkchens am meisten entschuldigen möge, ist die Schwierigkeit der Auffindung der nöthigen Quellen und Belege.” Keesbacher, Die Philharmonische Gesellschaft, 3.

7 The author is grateful to Renata Zadaravec Pešec from the Institute of Information Science (IZUM) for kindly providing the data included in the table from the COBISS system. 
More than decade after Keesbacher (1877), Peter Radics also speaks of the "historical development" of music in Carniola in the work Frau Musica in Krain (Lady Music in Carniola) ${ }^{8}$ His ambition is certainly greater, as he does not confine himself to an individual music institution. Moreover, he seeks broader social connections and speaks about more prominent figures, even going beyond their activities in Carniola. In the title, he presents the institutional, social, cultural and concert life associated with music as a "cultural-historical sketch". His intention is "to sketch a picture of the historical development of the musical essence in Carniola, especially in the capital, 'white Ljubljana', as it is called in our folk song". ${ }^{9}$

It is interesting that Keesbacher also deals with "national Slovenian composers" (national-slovenische Componisten) ${ }^{10}$ in one of the chapters. Although thus seeking to have a broad view, the title indirectly reveals a polarisation whose political connotation had a special significance and evidently also influenced musical historiography: "national Slovenian composers" are something different from all other composers. Thus, even seemingly unburdened historical surveys are always defined by a particular ideational/ideological role and reception. It is therefore difficult to speak simply of the unburdened "arousing of memory and imagination" that Steska unrealistically longs for.

Although Dragotin Cvetko's endeavours were also marked by a striving for objective, ideologically unburdened historiography, in 1977 he maintained a similar distinction (albeit with an inverted sign), as is evident, for instance, in the designation of Radics and Keesbacher as authors who had only indirectly contributed to Slovenian music historiography. Despite the indisputable value of both sources for gaining a knowledge the musical past in Slovenia, Cvetko treats them with a certain scepticism:

\begin{abstract}
To the extent that they existed, Slovenian musicological discussions in the interwar period unfolded in three directions. Most of these discussions were in the field of music historiography, whose initial beginnings, along with certain results, were evident as early as towards the end of the nineteenth century and at the very beginning of the twentieth century. In this regard, one should recall writers such as Fran Rakuša, Anton Trstenjak, Viktor Steska and Davorin Beranič, as well as Peter Radics and Friedrich Keesbacher, who contributed at least indirectly to Slovenian musical historiography. ${ }^{11}$
\end{abstract}

Cvetko's starting point should undoubtedly also be understood in the context of affirming musicology as a science that only gradually shrank its space,

8 Peter Radics, Frau Musica in Krain: Kulturgeschichtliche Skizze (Ljubljana, 1877).

9 Radics, Frau Musica, 5.

10 Ibid., 43.

11 Dragotin Cvetko, "Današnje stanje slovenske muzikologije," Muzikološki zbornik 13 (1977): 5-6, https://doi.org/10.4312/mz.13.1.5-13. 
largely through emphasising its importance for the formation and consolidation of national identity. The fact that it is a case of conceiving musicology in a broad sense is also indicated by the title of the article "Današnje stanje slovenske muzikologije" ("The Current State of Slovenian Musicology"). The emphasised national character of the discipline understandably favoured the historical approach over the other approaches. In the continuation of the article, Cvetko therefore explicitly emphasises that the "most important issue" of the direction of development of musicology after the Second World War indicated the need for an orientation towards historiography:
[...] most important was the question of where, to which field, Slovenian musicol- ogy would go first at a moment when music scholarship in the international space had already broadly determined itself and developed a number of independent disciplines within its framework. It chose [actually, Cvetko himself chose] the historical direc- tion, that is, the history of music, which is still the central discipline elsewhere, and is now buoyed by new insights into the systematics of researching and dealing with the- matic material. This was given priority. More than general history, Slovenian musicol- ogy was interested in the history of Slovenian music, in order to make it 'accessible to cognition on domestic soil', and to become an 'integral part of the history of world music', which had not happened to date, because it simply had not yet existed. ${ }^{12}$

The developmental tasks of musicology are therefore evident above all in the need to create a historical outlook, in the function of both national validation and the gradual integration of Slovenian music into the broader, global cultural context. Cvetko also applied these principles in designing the curriculum of the university musicology course. In so doing, he specifically modified Adler's polarisation, as can be clearly understood from the anthology published on the occasion of the university's $50^{\text {th }}$ anniversary. ${ }^{13} \mathrm{He}$ refers to the history of music as "the leading discipline in musicology", ${ }^{14}$ also in relation to musical practice, labelling all other non-historical sub-disciplines as "auxiliary musicology disciplines":

Candidates for musicology must bring this knowledge [practical music knowledge] with them in part, and in part acquire it at the faculty, which does not significantly burden their main, musicology studies. It is the latter to which central concern is devoted, with an emphasis on the history of music, with measured consideration given to the auxiliary musicology disciplines. ${ }^{15}$

12 Cvetko, "Današnje stanje," 8; Cvetko also referred to the Introduction to the first issue of the Muzikološki zbornik. Dragotin Cvetko, "Uvodna beseda," Muzikološki zbornik 1 (1965): 5-7.

13 Dragotin Cvetko, "Muzikologija," in Petdeset let slovenske univerze v Ljubljani:1919-1969, ed. Roman Modic (Ljubljana: Univerza v Ljubljani, 1969), 279-282.

14 Cvetko, "Muzikologija," 279.

15 Ibid., 281. 
In the 1980s, a similar conception was held by Jože Sivec, ${ }^{16}$ who speaks about the place of historiography within musicology. Outlining the beginnings of the Department of Musicology, he writes: "The department immediately focused primarily on music history, which was, and still is, the strongest of the musicology professions in the world." ${ }^{17}$ In an article that speaks about the endeavours of Slovenian musicology, paradigmatically entitled "Razvoj in dosežki glasbenega zgodovinopisja na Slovenskem" ("The Development and Achievements of Music Historiography in Slovenia"), Sivec relies on Cvetko's paradigm of emphasising national importance in justifying musicology as it developed in the period after 1945: "The realisation emerged that the place of musicology, and thus also of music history [!], is among the national sciences." ${ }^{18}$ In the defence of national interests, however, it should be emphasised that, unlike Cvetko, Sivec also unequivocally includes Keesbacher and Radics in his survey.

Cvetko's position evolved gradually, and we can discern it indirectly from his article on the place and importance of the national university, ${ }^{19}$ published as early as during the interwar period (1936).

\begin{abstract}
Science works not only in a global sense, but also performs specific tasks for particular territories. Our own science will itself most successfully solve specifically Slovenian scientific questions: the development of the Slovenian language, Slovenian literature and history, Slovenian pedagogy, Slovenian art, Slovenian law, etc., along with all of the aspects necessary for the proper interpretation. Every university owns this right, knowing that it has a duty to preserve the nation's culture, to hand it down to future generations, thus enriching them..$^{20}$
\end{abstract}

The main task of the university and of science in general is to "maintain and develop culture":

It does not matter which profession one pursues: worker, craftsmen, farmer, clerk ... As I have emphasised earlier, the academic profession is fundamentally a leadership role. In his treatise 'Die Ethik der Berufsberatung', Dunkmann emphasises that the core professions are those whose role is to maintain and develop culture, that is, the academic professions. The latter should introduce education into all of the levels in which they are engaged. The proper execution of the profession influences the growth of the personal value of the individual, while at the same time having a beneficial effect on raising the level of culture. ${ }^{21}$

16 Jože Sivec, "Razvoj in dosežki glasbenega zgodovinopisja na Slovenskem," Muzikološki zbornik 17, no. 2 (1981): 145-181, https://doi.org/10.4312/mz.17.2.145-181.

17 Sivec, "Razvoj in dosežki," 150.

18 Ibid., 150 .

19 Dragotin Cvetko, "Kulturni pomen sodobne in posebej slovenske univerze," Sodobnost 4, no. 10 (1936): 470-475.

20 Cvetko, "Kulturni pomen," 474.

21 Ibid., 473-474. 
Cvetko's understanding of musicology inside the system of contemporary sciences within the framework of the (national) university grew in its reliance on the modern systematisation of science, as developed in particular within the art history and literary history schools. One of the first theorists to write about the system of musicology was Stanko Vurnik. Vurnik's ideas, which he developed from a parallel with fine art theory, are indirectly presented by France Stele in a review of Vurnik's Uvod v glasbo (Introduction to Music). Stele believes that Vurnik transferred the system from Cankar's Uvod v razumevanje likovne umetnosti (Introduction to the Understanding of the Fine Arts) to musicological analysis, affectionately referring to it as "musical cognitive": "He wanted to use it [Cankar's system] for musical cognitive purposes, while, at the same time, he attempted to test whether the basic findings that Cankar determined for all areas of the fine arts are also valid for other fields, especially music." 22

It seems that Cvetko was particularly influenced by Vurnik's commitment to historiography, to which he gave priority over any other "conceptual speculation", as he puts it. Vurnik elaborated his position particularly clearly and sharply in his polemic with Josip Vidmar. ${ }^{23}$ In dealing with art, he wants to be "completely determinably concrete", as he genially says, emphasising the "huge difference between conceptual-speculative and concrete-historical knowledge of art". ${ }^{24}$

"It is unfortunate that, in Slovenia, art history needs to be - defended! On the bright side, it is only those who are unfamiliar with art history that excoriate it!" 25 One can understand this as a reference to Vidmar.

\begin{abstract}
It must be an awful truth, albeit old, for speculators that art is not an invisible allegorical figure floating somewhere in the air as an object of metaphysics; rather, it is all contained in the artworks created so far. No science, no cognition that seeks to take art as its object, can ignore this concrete object and gain an understanding in thin air; thus the only specialised science of art is art history and its ancillary branches, the only scientific art cognition is art history, the only scientific system is that which is taken from the body of the object and corresponds to it uniquely. ${ }^{26}$
\end{abstract}

Vurnik even labelled the unhistorical treatment of art as a "disease of philosophical abstraction and speculation" that attacked "that sick child of former modernism, the philosophy of art, but ran amuck worst of all in journalistic criticism, where, unfortunately, it was the most fruitful way for uneducated speculators to gain a reputation". ${ }^{27}$ umetnosti," Dom in svet 40, no. 8 (1927): 278-281. 
He thus sharply rejects the phenomenological deconstruction of art. When the latter removes from art "one after another, its temporal, local, etc. attachment", it gains, according to Vurnik, "non-temporality, by which that [...] 'artwork' has automatically ceased to be an object of art history." 28

\section{Palpable proof of how, with the aid of this overly scientific system, it is possible to banish the object of this science from the world! Really, if you have to correct and operate on living art in order to make your system correspond to it, then that was not art; God forbid such an art system, in our case 'conceptual abstract speculation'. ${ }^{29}$}

Nonetheless, after the transfer of the musicology (history) department from the Academy of Music to the Faculty of Arts, Cvetko began to engage in a wider sphere of musicological research, as well. In this sense, a division was formed into systematic and (predominant) historiographic study areas within the Department of Musicology, with the latter in particular indicating its orientation with its work subsequent to the founding of the Musicological Institute at the Research Centre of the Slovenian Academy of Sciences and Arts. In this regard, we can (self-)critically affirm Bujićs caveat that "the monuments of Slovenian musical art (Monumenta artis musicae sloveniae) were gradually becoming a worthy monument to musicological endeavour". ${ }^{30}$

Musicology thus outwardly identified itself above all as a "retrospective discipline" ${ }^{31}$ which, in its conception of the work, assumes its own perspective through which the meaning of the text is established and gradually radicalised in the search for the genuine "original", in the sense of the "Urtext" and its most faithful reproduction. As Nicholas Cook succinctly puts it: "Musicology has traditionally been a retrospective discipline, [...] turning time back so as to arrive at the Urtext." ${ }^{2}$

This retrospective outlook reached its apex in the advocation of "historically informed musical practice". In Slovenia, the beginning of this kind of endeavour is represented by the musical-practical revival of numerous early works under the leadership of Mirko Cuderman. These ideas were deepened by Klemen Ramovš and Tjaša Krajnc, as well as by Domen Marinčič and Tomaž Sevšek. The issue of historical analysis and the revival of early music is also addressed by Klemen Grabnar and Katarina Šter, while Jurij Snoj and Tone Potočnik are engaged in the area of Gregorian chant.

28 Ibid., 279.

29 Ibid., 279.

30 Bojan Bujić, "A Hundred or so Years of Musicology: What have we Learned?" in Glazba prijelaza: Svečani zbornik za Evu Sedak/Music of Transition: Essays in Honour of Eva Sedak, eds. Nikša Gligo, Dalibor Davidović, and Nada Bezić (Zagreb: ArTresor/HRT, Zagreb, 2009), 61.

31 Nicholas Cook, "We are All (Ethno)musicologists Now," in The New (Ethno)musicologies, ed. Henry Stobart (Lanham, Md.: Scarecrow Press, 2008), 58.

32 Cook, "We All (Ethno)musicologists," 58. 
It is in fact retrospective historicism, with its focus on the concept of the work, that emphasised the importance of the ontological and cognitive consideration necessary for understanding, interpreting and evaluating the work. It is precisely the emphasised concept of the work that required a deepening of systematic musicological research, a more demarcated system of musicological subdisciplines, and a more complexly woven network of interdisciplinary research. Thus, in Slovenia, too, the view of new fields and procedures of the musicological study of music strengthened, from music aesthetics and psychology, to sociology and anthropology, acoustics and theory, ethnomusicology and folkloristics. The circle of these studies and reflections in Slovenia was undoubtedly significantly bolstered by the arrival of Marija Bergamo at the Department of Musicology - of course, on Cvetko's invitation. Some of the early works of Janez Höfler and Primož Kuret were focused on musical iconography, as well. Later, Darja Koter also devoted herself to this, although her research work dealt primarily with the study of instrument making in Slovenia.

A number of researchers made a significant contribution to the expansion of the fields of musicology. Of interest is acoustic research (from Miroslav Adlešič, to Bruno Ravnikar and Drago Kunej), as well as ethnomusicological discussions (from Zmaga Kumer, to Julijan Strajnar and a number of younger researchers, such as Svanibor Pettan, Urša Šivic, Mojca Kovačič, Simona Moličnik, and others).

The musical-analytical focus on structure and its complex networks offered, among other things, a refuge from politicisation and the associated (ideological and any other functional) use of music for non-musical purposes, which was especially pronounced during the Third Reich and the socialist dictatorship. It is therefore no wonder that it received its strongest reverberation in Slovenia in the modernist reaction, especially from the 1960s onwards. The search for composers was accompanied by a wealth of music-analytical work, as was announced by the in-depth contributions of Andrej Rijavec, Marija Bergamo, Borut Loparnik and Zoran Krstulović, and later in the analysis of Žebre's music by Karmen Salmič Kovačič, as well as in the extensive work by Leon Stefanija, Gregor Pompe, Larisa Vrhunc, and others. The treatment of the music-theoretical writing of Radovan Škrjanc and Nejc Sukljan can also be included in this circle.

Bohlman points out, however, that "the most hegemonic form of politicisation of music" is the historical ability of musicology, which has shown "a remarkable capacity to imagine music into an object that [has] nothing to do with political and moral crises". ${ }^{33}$ In the cause-and-effect change of emphasis within musicology, it seems self-evident, as well as substantively paradoxical, that with greater emphasis on musical works the conditional expansion of the 
view of musicological study by the conditions and contexts of philosophical, social and, consequently, reception and meta-interpretive domains, resulted in a shift away from the previously dominant concept of the musical work and the system of science that had developed on its basis. ${ }^{34}$ The turn "beyond text", as can be observed in numerous contemporary musicological utterances, conceptual reflections and, not least, research orientations, goes "beyond the assumption that the score and its apparent embodiment of composers' intentionality can be taken as tantamount to musical experience". 35

The turning point in Slovenian musicology was indicated by the aforementioned expansion of research to the fields of music sociology and aesthetics by Marija Bergamo, and not least in the writings of Andrej Rijavec and Jože Sivec, many of whose articles establish an analysis of institutional and genre conditions (opera, musical theatre, city pipers, etc.) for the design of music, rather than focusing on the musical work and its creator. Their efforts were continued in numerous articles by younger musicologists, from Simona Moličnik, to Nataša Cigoj Krstulović, Urška Šramel Vučina, Alenka Bagarič, and so on.

The turnaround, also referred to as an "ontological transformation", has affected both the object itself and the research relations. As Born puts it: "an orientation apparent in diverse interdisciplinary practices in each of the fields that we studied towards effecting ontological transformation in both the objects and the relations of research." ${ }^{36}$ In a provisional sense, this can already be perceived in Cvetko's endeavours to transform the image of the autonomy of Slovenian musical culture. This kind of "regional epistemology" is typical of modern science, which is characterised by the dispersion of specialisations and the development of new territories, disciplines and branches of knowledge. ${ }^{37}$ Within musicology, in addition to the many new fields of the so-called "new musicology", this is especially evident in the keen interest in the issues of reception and interpretation history, which have required a turn towards understanding the hermeneutic context. In the postmodernist manner, this has erased the formerly prevalent paradigms of big national stories, on whose ruins, not least in Slovenia in recent decades, have grown the fragmented story of individual narratives.

Metoda Kokole forms her highly systematic and in-depth contribution in the critical position of historical musicology, while Jernej Weiss's research is also focused on broad historiographical fields, in a certain sense complementing the work of Maruša Zupančič.

Lydia Goehr, The Imaginary Museum of Musical Works: An Essay in the Philosophy of Music (Oxford: Clarendon Press, 1992).

35 Georgina Born, "For a Relational Musicology: Music and Interdisciplinarity: Beyond the Practice Turn," Journal of the Royal Musical Association 135, no. 2 (2010): 218.

36 Born, "For a Relational Musicology," 212.

37 Ibid., 209. 
Although seemingly faithful to traditional historical research, Radovan Škrjanc's work, both in his analysis of the work of Jakob Frančišek Zupan and his analysis of church music, shows a marked turn in the direction of critical analysis of traditional procedures, replacing the usual treatment of the sequence of events by seeking a more convincing Foucauldian model of historical structures.

Aleš Nagode's thorough deconstruction of the concepts of Slovenian music histography is undoubtedly crucial for the image of musicological research today. Although committed to an extraordinary breadth of exploration of Slovenia's musical past, his work is characterised by a consistent critical distance, on which he builds more solid phenomenological starting points.

A similar criticalness marks the work of Katarina Bogunović Hočevar, in her meta-analysis of established stylistic definitions, and not least in her discussion of Cvetko's musicological legacy. It is in this sense that one should also understand the critical review of early symphonic creativity in Slovenia by Vesna Venišnik.

Important in terms of developing fresh and new approaches is the work of Jurij Snoj, who even introduces the traits of semiotic analysis to the study of Gregorian chant. This is complemented by Gregor Pompe, in whose work we find a marked reflection on the semiotic-semantic nature of music. Of particular value is the cooperation between Snoj and Pompe, which has produced an excellent common result in the analysis of the history of music notation in Slovenia. In this regard, it is significant that Pompe, with his choice of research topics, clearly indicates a shift from the narrowly oriented "regional epistemology" of national history writing towards the field of broadly comparable music analysis.

On the other hand, semiological analysis is combined with hermeneutically critical ideas and epistemology in the work of Leon Stefanija, who builds upon the meta-analysis of analytical procedures by reflecting on analytical methodologies, even within seemingly traditional biography (Rojko).

As early as in the 1970s, on marking the bicentenary of Beethoven's birth, Hans Heinrich Eggebrecht challenged the "old humanist concept" of the traditional futility of the humanities, as espoused by Loos. ${ }^{38}$ Eggebrecht contrasts this with a sociology-oriented musicology that "reflects its purpose from the definition and needs of modern society in terms of progress and [...] seeks points (such as at school) where it can be socially useful in a practical way". ${ }^{39}$

38 Helmut Loos, E-Musik - Kunstreligion der Moderne: Beethoven und andere Götter (Kassel: Bärenreiter, 2017), 98.

39 "[...I]hren Zweck aus der Definition und den Notwendigkeiten der gegenwärtigen Gesellschaft unter dem Aspekt des Fortschritts [reflektiert] und [...] die Punkte (z. B. in der Schule) [sucht], wo sie gesellschaftlich praktisch werden kann." Hans Heinrich Eggebrecht, "Konzeptionen," in Bericht über den Internationalen Musikwissenschaftlichen Kongreß Bonn 1970, eds. Carl Dahlhaus, Hans-Joachim Marx, Magda Marx-Weber, and Günther Massenkeil (Kassel: Bärenreiter, [1971]), 650 . 
The dilemma of the seeming futility of the humanities seems to have caused discomfort and resistance in science itself, leading to demands for more explicit applicability, as is strongly represented by Svanibor Pettan within the concept of "applied ethnomusicology". The focus on musical practices and their diversity within ethnomusicological studies has also influenced the idea of musics, used in the plural. This is joined by a demand to extend the conceptual boundaries of contemporary musicology to the field of popular music, as well. ${ }^{40}$

Nicholas Cook provocatively asserts that "we are now all ethnomusicologists", ${ }^{41}$ prompting Born to label him as a "marriage broker". ${ }^{42}$ According to Cook, by shifting its focus from meaning to the empirical study of performance and practice, musicology has become distinctly more ethnomusicological, while, conversely, ethnomusicology has become more musicological, as it deals with, for example, outstanding musicians, music events, and so on. Gary Tomlinson, too, believes that "musicology needs to embrace the fact of its position within a more general ethnomusicology." ${ }^{33}$

When David Beard and Kenneth Gloag ${ }^{44}$ seek to define the musicological currents of recent decades, proceeding from a typical postmodernist turn they simply refer to "musicology before and after Kerman", thus adopting Joseph Kerman as a useful contemporary myth: "a "before Kerman/after Kerman paradigm' may be a myth, yet, 'as myths go, this is quite a helpful one'." 45

In so doing, they point out that,

For some, musicology after Kerman may be marked by a sense of loss, a nostalgia for musicology past, while, for others, the current state of the discipline is better for the critical reflection inspired by Kerman. It also provides a reference point, a moment against which departures can be measured.

It is possible, therefore, that musicology becomes more critical and less positivistic, more concerned with interpretations and less with facts [...]. It has also become more interdisciplinary as the boundaries between different types of music are partially erased and the search for new critical models pushes way beyond the limits of a traditional musicology. ${ }^{46}$

It is therefore worth posing the question as to whether we can talk about some kind of new musicology "after Kerman" in Slovenia, as well. Can we, in

40 John Covach, "Popular music, Unpopular Musicology," in Rethinking Music, eds. Nicholas Cook and Mark Everist (Oxford: Oxford University Press, 1999), 452-470.

41 Cook, "We All (Ethno)musicologists," 65.

42 Born, "For a Relational Musicology," 215.

43 Gary Tomlinson, "Musicology, Anthropology, History," in The Cultural Study of Music: A Critical Introduction, eds. Martin Clayton, Trevor Herbert, and Richard Middleton (London: Routledge, 2003), 216.

44 David Beard and Kenneth Gloag, Musicology: The Key Concepts (London and New York: Routledge, 2005).

45 Beard and Gloag, Musicology, viii.

46 Ibid., xii-xiii. 
Slovenia, also detect a sense of loss and a certain nostalgia for past musicology, or has musicology now opened up to new critical reflection that enriches musicology? Has musicology in Slovenia become more critical and less positivistic? Is it more concerned with interpretation and less with facts? Has it evolved towards an interdisciplinary search for new critical models that place it beyond the boundaries of traditional musicology?

A review of the musicology projects approved in recent decades reveals a trend towards emphasising increasingly specific issues and interdisciplinary connections at the expense of traditional archival work and historical periodisation. Notwithstanding the fact that this does, of course, partly reflect the orientation of contemporary research funding policy, it nevertheless indicates a broader epistemological change in direction.

A historical shift of direction does not, however, always necessarily mean a change towards something better and more complete, as the application of an evolutionary model of the development of science might otherwise attempt to convince us. In my opinion, the planned publication of a new history of Slovenian music paradigmatically highlights the dilemmas of Slovenian musicology today. The need to write a comprehensive history of Slovenian music undoubtedly indicates a distinct shortcoming in the collection and processing of certain basic facts that we can observe in the study of Slovenian music. On the one hand, there is therefore a clear need for a factual, historicist view that renounces broader interdisciplinary and critical premises. On the other hand, we can also observe an emphasised interpretation and reception history, a (re)interpretation of the history of institutions, and discussion of genre definitions, acoustic facts, theoretical implications, social relations, critical reflection, and so on. This can, however, also bring with it fragmentation and disintegration, with individual sub-disciplines increasingly rarely engaging in dialogue, thus further enhancing feelings of insecurity, self-doubt and perhaps even distrust. As Cook and Everist put it: "the history of musicology and music theory in our generation is one of loss of confidence: we no longer know what we know." ${ }^{47}$

Could the words "we no longer know what we know" also indicate the state of contemporary musicology in Slovenia? Georgina Born's proposal to establish contemporary musicology as "relational musicology" 48 poses a dilemma for Slovenian musicology (as well). On the one hand, this proposition grows from traditional humanist roots, but, at the same time, it is faced with questions of defining science on the edge of an awareness of the multicoloured nature of contemporary music theories and practices. The discontinuities, voids and inhomogeneities that can be perceived in Slovenian musicology are not merely a consequence of the discrepancy between musical experience and musical

47 Nicholas Cook and Mark Everist, eds., Rethinking Music (Oxford: Oxford University Press, 1999): v.

48 Born, "For a Relational Musicology," 205-243. 
discourse, or the result of some propaedeutic lack of thought, but rather one of today's musicological modes, torn between basic ontological questions, caught in the referential contexts of different musical systems.

\section{Bibliography}

Beard, David, and Kenneth Gloag. Musicology: The Key Concepts. London and New York: Routledge, 2005.

Bock, Emil. Die Philharmonische Gesellschaft in Laibach: 1702-1902. Ljubljana: Direktion der Philharmonischen Gesellschaft, 1902.

Bohlman, Philip V. “Musicology as a Political Act.” Journal of Musicology 11 (1993): 411-436.

Born, Georgina. "For a Relational Musicology: Music and Interdisciplinarity: Beyond the Practice Turn." Journal of the Royal Musical Association 135, no. 2 (2010): 205-243.

Bujić, Bojan. "A Hundred or so Years of Musicology: What have we Learned?" In Glazba prijelaza: Svećani zbornik za Evu Sedak/Music of Transition: Essays in Honour of Eva Sedak, edited by Nikša Gligo, Dalibor Davidović, and Nada Bezić, 61-68. Zagreb: ArTresor/HRT, Zagreb, 2009.

Cook, Nicholas, and Mark Everist, eds. Rethinking Music. Oxford: Oxford University Press, 1999.

Cook, Nicholas. "We are All (Ethno)musicologists Now." In The New (Ethno)musicologies, edited by Henry Stobart, 48-70. Lanham, Md.: Scarecrow Press, 2008.

Covach, John. "Popular music, Unpopular Musicology." In Rethinking Music, edited by Nicholas Cook and Mark Everist (Oxford: Oxford University Press, 1999), 452-470.

Cvetko, Dragotin. “Današnje stanje slovenske muzikologije.” Muzikološki zbornik 13 (1977): 5-13.

Cvetko, Dragotin. "Kulturni pomen sodobne in posebej slovenske univerze." Sodobnost 4, no. 10 (1936): 470-475.

Cvetko, Dragotin. "Muzikologija." In Petdeset let slovenske univerze v Ljubljani: 1919-1969, edited by Roman Modic, 279-282. Ljubljana: Univerza v Ljubljani, 1969.

Cvetko, Dragotin. "Uvodna beseda.” Muzikološki zbornik 1 (1965): 5-7.

Eggebrecht, Hans Heinrich. "Konzeptionen.” In Bericht über den Internationalen Musikwissenschaftlichen Kongreß Bonn 1970, edited by Carl Dahlhaus, Hans-Joachim Marx, Magda Marx-Weber, and Günther Massenkeil, 648-650. Kassel: Bärenreiter, [1971].

Goehr, Lydia. The Imaginary Museum of Musical Works: An Essay in the Philosophy of Music. Oxford: Clarendon Press, 1992.

Keesbacher, Friedrich. Die Philharmonische Gesellschaft in Laibach seit dem Jahre ihrer Gründung 1702 bis zu ibrer letzten Umgestaltung 1862: Eine geschichtliche Skizze. Ljubljana, 1862.

Loos, Helmut. E-Musik - Kunstreligion der Moderne: Beethoven und andere Götter. Kassel: Bärenreiter, 2017.

Radics, Peter. Frau Musica in Krain: Kulturgeschichtliche Skizze. Ljubljana, 1877.

Sivec, Jože. "Razvoj in dosežki glasbenega zgodovinopisja na Slovenskem." Muzikološki zbornik 17 (1981): 145-181. https://doi.org/10.4312/mz.17.2.145-181.

Stele, France. "Stanko Vurnik: Uvod v glasbo; I. Sistematični del." Dom in svet 42, no. 5 (1929): 157.

Steska, Viktor. "Academia Philo-Harmonicorum v Ljubljani: Ob dvestoletnici (1702-1902).” Dom in svet 15, no. 4 (1902): 234-237. http://www.dlib. si/?URN=URN:NBN:SI:DOC-21X3C5PZ. 
Tomlinson, Gary. "Musicology, Anthropology, History." In The Cultural Study of Music: A Critical Introduction, edited by Martin Clayton, Trevor Herbert and Richard Middleton, 31-44. London: Routledge, 2003.

Vurnik, Stanko. "Polemika k poglavju o pojmovno-spekulativnem in historičnem spoznavanju umetnosti." Dom in svet 40, no. 8 (1927): 278-281.

\section{POVZETEK}

\section{Sodobna muzikologija in preučevanje glasbenih praks na Slovenskem}

Muzikologija na Slovenskem se je porojevala iz glasbenega zgodovinopisja, ki ga je v njegovi zgodnejši fazi V. Steska označil z besedami »zbujati spomine in napolniti domišljijo z nedopovedljivim čarom«. Počasi je prek Keesbacherja in Radicsa začelo razgrinjati kompleksnejše družbene povezave in predstavljati tudi širšo institucionalno, družabno, kulturno in koncertno življenje. Pri tem je pisanje pogosto vodilo poudarjeno ideološko zaznamovano izhodišče, ki ga je še pri D. Cvetku mogoče razumeti v kontekstu potrjevanja muzikologije kot vede, ki si je svoj prostor krčila tudi prek utrjevanja nacionalne identitete. Razvojne naloge muzikologije pa hkrati kažejo tudi prizadevanje po postopnem vključevanju slovenske glasbe v širši, globalni kulturni kontekst, kot to izpostavlja J. Sivec, ko govori o mestu zgodovinopisja znotraj muzikologije.

Cvetkovo razumevanje muzikologije znotraj sistema sodobnih znanosti je raslo v naslonu na sistematizacijo, kot se je razvijala zlasti z I. Cankarjem in S. Vurnikom znotraj umetnostnozgodovinske in literarnozgodovinske šole. Ob bok temu se je začel odpirati tudi širši krog muzikoloških raziskav. Historicizem je namreč z osredotočenjem na koncept dela izpostavil pomen ontološkega in spoznavnega premisleka, nujnega za razumevanje, interpretiranje in vrednotenje dela. S tem je v ospredje stopil sistem sistematičnomuzikoloških poddisciplin ter mreža interdisciplinarnih raziskav, od glasbene estetike, do psihologije, sociologije, antropologije, akustike, teorije, etnomuzikologije idr.

Glasbeno-analitično osredotočanje v strukturo in njene kompleksne mreže je med drugim obljubljalo zatočišče pred politizacijo glasbe. Svoj odmev je dobilo v modernistični reakciji od šestdesetih let naprej. Iskanja ustvarjalcev je spremljalo bogato glasbeno-analitično delo A. Rijavca, M. Bergamo, B. Loparnika, Z. Krstulovića, K. Salmič Kovačič, L. Stefanije, G. Pompeta, L. Vrhunc, R. Škrjanca, N. Sukljana idr.

Poznejši obrat »izza teksta« se je v slovenski muzikologiji nakazoval s širitvijo raziskav na področja glasbene sociologije in estetike pri M. Bergamo, A. Rijavcu in J. Sivcu. Svoje nadaljevanje so tovrstni poskusi doživljali v številnih prispevkih mlajših muzikologov, $\mathrm{S}$. Moličnik, N. Cigoj Krstulović, U. Šramel Vučina, A. Bagarič idr. V kritični poziciji historične muzikologije oblikuje svoj prispevek M. Kokole,J. Weiss in M. Zupančič. V smislu razvijanja novih pristopov izstopa delo J. Snoja, G. Pompeta in L. Stefanije.

Načrtovana izdaja nove zgodovine slovenske glasbe opozarja na dileme slovenske muzikologije danes. $\mathrm{Na}$ eni strani gre za manko pri zbiranju in obdelavi temeljnih virov, ki terjajo izdelan historicistični pogled. Na drugi strani pa lahko opazimo osredotočanje na recepcijsko zgodovino, (re)interpretiranje zgodovine institucij, pretresanje zvrstnih opredelitev, akustičnih dejstev, teoretskih implikacij, socialnih odnosov, kritiške refleksije ipd. To s sabo prinaša fragmentiranje in drobljenje, ki ovira intenzivnejši dialog in povečuje občutek negotovosti 
in nesamozavesti. Tako bi morda $\mathrm{z}$ besedami »Ne vemo več, kaj sploh vemo, « označili lahko stanje sodobne muzikologije pri nas. Diskontinuiteta, praznine, nehomogenosti, ki jih lahko zaznavamo v slovenski muzikologiji, tako niso nujno le posledica razkoraka med glasbeno izkušnjo in njenim diskurzom ali rezultat neke propedevtske nedomišljenosti, temveč eden od današnjih muzikoloških modusov, razpetih med temeljna ontološka vprašanja, ujeta $\mathrm{v}$ kontekste različnih referenčnih sistemov.

\section{ABOUT THE AUTHOR}

MATJAŽ BARBO (matjaz.barbo@ff.uni-lj.si) is a full professor at the Department of Musicology at the Faculty of Arts, University of Ljubljana. He is an author of several books and scientific articles. He has been a president of the Slovenian Musicological Society and for several years an editor of the journal Musicological Annual. His research focuses on music from the $18^{\text {th }}$ century to the present, especially that which is associated with Slovenian cultural life, the development of symphonic music and selected questions related to the aesthetics of music.

\section{O AVTORJU}

MATJAŽBARBO (matjaz.barbo@ff.uni-lj.si) je redni profesor na Oddelku za muzikologijo Filozofske fakultete Univerze v Ljubljani. Je avtor več knjig in znanstvenih prispevkov, bil je predsednik Slovenskega muzikološkega društva ter dolgoletni urednik revije Muzikološki zbornik. V svojih raziskavah se posveča glasbi od 18. stoletja do danes, zlasti v povezavi s slovenskim kulturnim življenjem, pa razvoju simfonične glasbe ter izbranim glasbeno-estetskim vprašanjem. 